\title{
POLYPHENOL-RICH DIET IS ASSOCIATED WITH DECREASED LEVEL OF INFLAMMATORY BIOMARKERS IN BREAST CANCER PATIENTS
}

\author{
Agnieszka Sut ${ }^{1}$, Maria Pytel ${ }^{2}$, Marek Zadrozny $^{3}$,Jacek Golanski ${ }^{1}$, Marcin Rozalski ${ }^{1}$ \\ ${ }^{1}$ Department of Haemostasis and Haemostatic Disorders, Medical University of Lodz, Lodz, Poland \\ ${ }^{2}$ Therapeutic and Diagnostic Oncological Centre Nu-Med., Tomaszow Mazowiecki, Poland \\ ${ }^{3}$ Department of Oncological Surgery and Breast Diseases, Institute of Polish Mother's Memorial Hospital, \\ Lodz, Poland
}

\begin{abstract}
Background. The study investigated the relationship between dietary intake of polyphenols and inflammatory markers: CRP, neutrophil/lymphocyte ratio (NLR), platelet/lymphocyte ratio (PLR), medium platelet volume/lymphocyte ratio (MPVRL), in newly-diagnosed breast cancer patients.

Objectives. The aim of this work was to verify whether diet rich in plant polyphenols affects inflammatory markers in breast cancer patients.

Materials and methods. 78 patients (55.3 \pm 14.5 years) treated surgically for breast cancer were studied. A modified FFQ and authorial worksheet based on the Phenol Explorer database was used to measure the amount of plant polyphenols in a diet. Basing on the median of polyphenols intake (1780 mg/day), the group was divided into two subgroups: low- and high- dietary intake of polyphenols (LDIP and HDIP, respectively). Plasma CRP level was measured and NLR, PLR and MPVLR were calculated using results from peripheral blood morphology.

Results. LDIP was associated with significantly higher CRP (elevated in 34.5\% LDIP patients vs. 8.3\% HDIP, p<0.003), NLR (elevated in 46.2\% LDIP patients vs. 25.6\% HDIP, p<0.006) and PLR level (elevated in 25.6\% LDIP patients vs. $12.8 \%$ HDIP, $\mathrm{p}<0.03$ ). MPVLR was not significantly different between both the subgroups.

Conclusion. High dietary intake of polyphenols remarkably reduced process of inflammation in breast cancer patients, which has important clinical implications. The study demonstrated also an usefulness of simple, cheap and commonly available biomarkers for monitoring anti-inflammatory effects of diet.
\end{abstract}

Keywords: polyphenols, diet, breast cancer, inflammation, inflammatory markers

\section{STRESZCZENIE}

Wprowadzenie. Badano zależność pomiędzy pobraniem polifenoli wraz z dietą a poziomem markerów stanu zapalnego: CRP, wskaźnika neutrofile/limfocyty (NLR), płytki/limfocyty (PLR) oraz średnia objętość płytek/limfocyty (MPVLR) wśród nowo zdiagnozowanych pacjentek z rakiem piersi.

Cel. Celem pracy było zweryfikowanie czy dieta bogata w polifenole roślinne wpływa na parametry stanu zapalnego u pacjentek z rakiem piersi.

Materiały i metody. Do badania włączono 78 pacjentek ( $55.3 \pm 14.5$ lat) klasyfikowanych do leczenia chirurgicznego raka piersi. Do oszacowania zawartości polifenoli w diecie użyto zmodyfikowanego zwalidowanego FFQ i autorskiego arkusza opartego na bazie Phenol Explorer. Po wyliczeniu median spożycia polifenoli (1780mg/dobę), podzielono pacjentki na dwie grupy: niskiego i wysokiego spożycia polifenoli (odpowiednio LDIP I HDIP). Zmierzono stężenie CRP oraz na podstawie wyników morfologii krwi obwodowej wyliczono wskaźniki NLR, PLR oraz MPVLR

Wyniki. W grupie z niższym pobraniem polifenoli zaobserwowano znacząco wyższe wartości CRP (podwyższone u 34.5\% vs grupa wysokiego spożycia $8.3 \%, \mathrm{p}<0.003$ ), NLR (podwyższone w $46.2 \%$ vs $25.6 \%, \mathrm{p}<0.006$ ) oraz poziom PLR (podwyższone u $25.6 \%$ vs $12.8 \%$, p<0.03). Wartości MPVLR nie różniły się istotnie pomiędzy podgrupami.

Wnioski. Wysokie spożycie polifenoli znacząco redukowało proces zapalny u pacjentek z rakiem piersi, co ma znaczące implikacje kliniczne. Badanie przedstawiło również użyteczność prostych, tanich i powszechnie dostępnych biomarkerów do monitorowania przeciwzapalnego wpływu diety.

Słowa kluczowe: polifenole, dieta, rak piersi, stan zapalny, markery zapalenia

Corresponding author: Agnieszka Sut, Medical University of Lodz, Department of Haemostasis and Haemostatic Disorders, Mazowiecka str. 6/8, 92-216 Lodz, Poland, tel: +48 426321721 sutagnieszka@gmail.com

(C) Copyright by the National Institute of Public Health - National Institute of Hygiene 


\section{INTRODUCTION}

Among females, breast cancer is the most commonly diagnosed cancer and the leading cause of cancer death [2], hence many scientists struggle to improve an effectiveness of breast cancer therapy and limit its side effects [33]. Major factors that increase the occurrence of that disease are alcohol consumption and overweight. Protective activity have lactation, physical activity and probably fruits, vegetable, soy and fish consumption. Nutrients as folate, calcium, vitamin D and fiber have also been taken into consideration [10]. A number of studies suggest that plant polyphenols play a protective role in carcinogenesis $[9,14,24]$. The risk of $\mathrm{BC}$ is significantly decreased among both pre- and post-menopausal women with high polyphenol intake $[6,9,14]$. The biological activity of polyphenols is manifested through several potential mechanisms: removing free radicals and increasing their dismutation to substances with lower activity $[16,19]$, modulation of immunological function and inhibition cancer initiation, promotion and progression, as well as platelet aggregation. There are studies indicating an anti-cancer activity of green tea and hawthorn fruit polyphenols as well as ellagic acid by performing cytostatic activity [16]. Concerning these potential activities, a diet rich in plant polyphenols can be very beneficial and may improve the treatment efficacy of cancer $[5,9,14]$.

There are many publications reporting the positive effect that plant polyphenols have on reducing CRP level $[3,20,23]$. Low-grade inflammation is characterized by elevated concentrations of inflammatory markers: plasmatic (C-reactive protein) and cellular (leukocyte and platelet counts and in neutrophil/lymphocyte ratio NLR) in the absence of any overt symptoms is recognized as a risk factor for a number of chronic diseases including cancer [1]. It is now widely accepted that chronic inflammation is closely associated with the process of cancer development. In the large study, effectiveness of inflammatory markers in predicting prognosis in 2374 women with BC was analysed, where NLR and PLR were found to be independent markers of prognosis in breast cancer, however further studies are needed in patients with overexpression of HER-2 [28].

In general, blood tests based on granulocyte, platelet and lymphocyte counts have identified a relationship between with poor prognosis in patients with $\mathrm{BC}$ and elevated NLR and PLR [29, 32]. Higher NLR correlates with decreased 5-year survival, greater tumour size, higher grading and metastasis occurrence. Higher PLR is known as a factor enhancing breast cancer risk. An preoperative PLR can be used as an independent prognostic marker for survival in breast cancer patients [12]. Additionally, when PLR was higher than 185 , reduced 5-year survival was observed [11]. One recently-described factor is MPVLR (mean platelet volume/lymphocyte ratio). However, while it is assumed to be a prognostic factor in CVD, further data is required to confirm this fact [8]. A review by Bonaccio et al., including MOLI-SANI study data, found that dietary polyphenol intake may reduce NLR, PLR and CRP values and protect against cancer [1]. Currently, there is no data, however, on the suitability of those simple inflammatory markers to monitor anti-inflammatory action of polyphenol-rich diet in breast cancer patients.

In response to the growing body of evidence concerning the anti-cancer and anti-inflammatory properties of dietary polyphenols, the aim of the present study was to determine whether a high dietary intake of polyphenols reduces the level of inflammatory markers in breast cancer patients. We analysed and compared CRP, PLR, NLR and MPVLR in two subgroups of breast cancer patients having lowor high dietary intake of polyphenols.

\section{MATERIAL AND METHODS}

\section{Patients}

A group of 78 breast cancer patients was studied (55.3 \pm 14.5 years). Patient recruitment was conducted in the Department of Surgical Oncology and Breast Diseases in Polish Mother's Memorial Hospital Research Institute. The inclusion criteria were as follows: the presence of loco-regional non-metastatic BC confirmed by histopathology; no previous oncological treatment. The exclusion criteria comprised the patient following an alternative diet (e.g. rigorous low-calorie diets, vegetarian diet, elimination diets) or taking medicines containing acetylsalicylic acid or other anti-platelets agents two weeks or shorter before the examination.

Patients were informed about the aim of the experiment and the potential risk associated with blood donation. All participants confirmed voluntary and conscious participation in the study.

For calculating cut off values of inflammatory markers, we used data coming from healthy reference group ( $\mathrm{n}=102)$ from our previous study [18].

\section{Laboratory tests}

Blood morphology (Sysmex XN-2000 automated haematology analyser, Sysmex Corporation, Kobe, Japan) results and CRP concentration (VITROS CRP Slide method, Ortho-Clinical Diagnostics, Inc, Rochester, NY, USA) were obtained from the hospital laboratory. On the basis of blood morphology data, the following markers (indexes) were calculated: PLR (platelet/lymphocyte ratio), NLR (neutrophil/lymphocyte ratio) and MPVLR (medium platelet volume/lymphocyte ratio).

Dietary questionnaire and the estimation of phenolic compounds intake

To estimate the nutritional value of a diet, including the vegetable phenolic compound content, 
a validated Food Frequency Questionnaire (FFQ) was used [7]. The data was entered into an authorial worksheet to estimate the content of the vegetable phenolic compounds. The worksheet was based on data from Phenol Explorer, a comprehensive database containing information about the quantity of 501 vegetable phenolic compounds (classified in six classes and 31 sub-classes) in 459 eatables. The products are classified into nine classes and 67 sub-classes. The common English name, French name, botanical family, scientific name, number of polyphenols and their medium quantity are given for each product, together with references for each substance.

The worksheet included the following classes: total quantity of vegetable phenolic compounds, flavonoids (alkylphenols, flavons, flavanols, catechins, procyanidins, antocyanins, teaflavins, dihydrochalcones, isoflavonoids), flavan-3-ols, phenolic acids (hydroxybenzoic acid, hydroxycynnamic acid), stilbenes and lignans.

\section{Statistical analysis}

Analyses were done with StatsDirect statistical software, version 2.7.8 (StatsDirect Ltd, Altrincham, UK). The results of inflammatory markers in patients are presented as the percentage of patients above the cut-off point (calculated separately for each inflammatory marker). Significance of differences were analysed using Fisher's exact test. Cohen's kappa coefficient was calculated as a measure of agreement. A kappa statistic value of $<0.4$ represents poor-to-fair agreement, a value of 0.41-0.60 reflects moderate agreement, a value of $0.61-0.80$ is considered good agreement, and a kappa value of $0.81-1.0$ is considered very good agreement.

\section{RESULTS}

\section{Dietary intake of polyphenols}

Using a validated FFQ, the dietary intake of polyphenols [7] was determined in the total of 78 middle-aged women with newly-diagnosed breast cancer. The median of total polyphenol intake was $1780 \mathrm{mg}$ per day. Using this value as the cut-off, the whole group of breast cancer patients was divided into a high dietary intake of polyphenols (HDIP) group $(n=39)$ and low dietary intake of polyphenols (LDIP) group $(n=39)$. The most abundant polyphenol sources in total breast cancer population were tea $(52.7 \%)$, coffee $(18.4 \%)$, fruits $(11.4 \%)$, vegetables $(6.7 \%)$, juices $(6.1 \%)$, cereal products $(2.5 \%)$, chocolate (2.1\%), seeds and oils $(0.2 \%)$.

All the participants were receiving breastconserving surgery or breast radical surgery as their first oncological treatment. The participating women were classified as follows: premenopausal (regular menstrual cycles in the past three months), postmenopausal (no menstrual period for over one year), were older than 55 years or had surgical menopause. Participants in both subgroups were well balanced according to age, BMI, smoking status, menopausal status, disease duration or family history of breast cancer. Breastfeeding was found to be significantly longer among the HDIP group of patients. No significant differences were found between HDIP and LDIP groups concerning the following tumour features: tumour grade, HER2 status, hormonal receptor status, Ki-67 status. The only differences between the HDIP and LDIP groups were in haemoglobin level and leukocyte count. The characteristics of the patients in HDIP and LDIP subgroups are shown in the Table 1.

\section{Inflammatory markers: cut-off points}

Cut-off values were defined based on inflammatory markers: plasmatic (C-reactive protein) and cellular (PLR, NLR and MPVLR) measured in the group of healthy volunteers not taking anti-inflammatory drugs $(n=102)$ [18]. Cut-off values were defined as 95th percentile of CRP, NLR, PLR and MPVLR. The values exceeding cut-off values were regarded as 'elevated' (over the normal range indicating higher inflammatory status) (Table 2).

\section{Inflammatory markers in breast cancer patients}

Overall, a total group of breast cancer patients (HDIP and LDIP together) ( $\mathrm{n}=78)$ was characterised by significant rise of all the inflammatory markers studied (CRP, NLR, PLR, MPVLR) in comparison with the control group (healthy subjects, $\mathrm{n}=102$ ) (Figure 1).

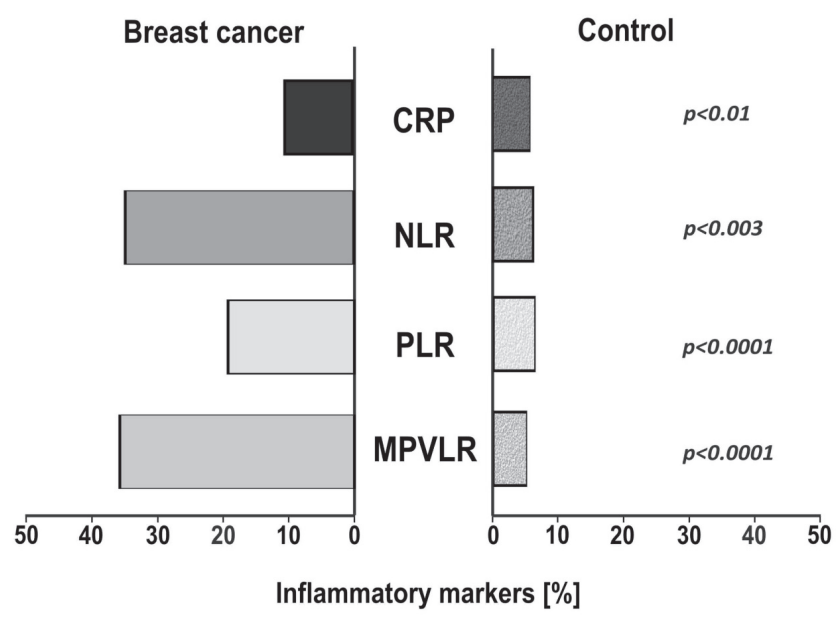

Figure 1. The comparison of plasma inflammatory markers (CRP) and cellular inflammatory markers (NLR, PLR, MPVLR) between breast cancer patients $(n=78)$ and control group $(n=102)$.

The results of inflammatory markers are presented as the percentage of individuals above the cut-off point. Cut-off values: CRP $>0.5$ $\mathrm{mg} / \mathrm{L}, \mathrm{NLR}>3.0, \mathrm{PLR}>207.0$, MPVLR $>6.8$. Significance of differences were analysed using Fisher's exact test. CRP: C-Reactive Protein, NLR: neutrophil-to-lymphocyte ratio, PLR: platelet-tolymphocyte ratio, MPVLR: mean platelet volume-to-lymphocyte ratio. 
Table 1. Characteristics of breast cancer patients $(\mathrm{n}=78)$ divided into subgroups with high- and low dietary intake of polyphenols

\begin{tabular}{|c|c|c|c|c|}
\hline \multicolumn{2}{|c|}{ Variable } & $\begin{array}{l}\text { High dietary intake of polyphenols } \\
\qquad \mathrm{n}=39\end{array}$ & $\begin{array}{l}\text { Low dietary intake of polyphenols } \\
\qquad \mathrm{n}=39\end{array}$ & $\begin{array}{c}P \\
\text { value }\end{array}$ \\
\hline \multicolumn{2}{|c|}{ Dietary intake of polyphenols [mg/day] } & $2230(1923-2394)$ & $1275(988-1541)$ & $<0.001$ \\
\hline \multicolumn{2}{|l|}{ Age (years) } & $56.9 \pm 14.1$ & $53.8 \pm 14.9$ & ns \\
\hline \multirow{2}{*}{\multicolumn{2}{|c|}{ BMI }} & $26.9 \pm 3,97$ & $27.1 \pm 4.64$ & ns \\
\hline & G1 & 3 & 2 & ns \\
\hline \multirow{3}{*}{ Tumour grade } & G2 & 16 & 18 & ns \\
\hline & G3 & 7 & 4 & ns \\
\hline & Unknown & 13 & 15 & ns \\
\hline \multirow{2}{*}{ HER2 status } & Positive & 2 & 4 & ns \\
\hline & Negative & 15 & 15 & ns \\
\hline \multirow{2}{*}{ ER status } & Positive & 14 & 15 & ns \\
\hline & Negative & 6 & 3 & ns \\
\hline \multirow{2}{*}{ PR status } & Positive & 13 & 14 & ns \\
\hline & Negative & 7 & 4 & ns \\
\hline \multicolumn{2}{|l|}{$\mathrm{Ki}-67[\%]$} & 40 & 36 & ns \\
\hline \multirow{2}{*}{ Menopausal status } & Postmenopausal & 27 & 26 & ns \\
\hline & Pre-menopausal & 12 & 13 & ns \\
\hline \multirow{2}{*}{$\begin{array}{l}\text { Breast cancer in } \\
\text { family }\end{array}$} & Yes & 12 & 15 & ns \\
\hline & No & 27 & 24 & ns \\
\hline \multicolumn{2}{|c|}{ Haemoglobin $(\mathrm{g} / \mathrm{dL})$} & $14.09 \pm 4.37$ & $13.02 \pm 1.37$ & ns \\
\hline \multicolumn{2}{|c|}{ Leukocyte count $\left(\times 10^{9} / \mathrm{L}\right)$} & $6.88 \pm 1.69$ & $7.67 \pm 2.03$ & ns \\
\hline \multicolumn{2}{|c|}{ Granulocyte count $\left(\times 10^{9} / \mathrm{L}\right)$} & $4.34 \pm 1.40$ & $5.08 \pm 1.80$ & $<0.04$ \\
\hline \multicolumn{2}{|c|}{ Lymphocyte count $\left(\times 10^{9} / \mathrm{L}\right)$} & $1.96 \pm 0.72$ & $1.78 \pm 0.71$ & ns \\
\hline \multicolumn{2}{|c|}{ Platelets count $\left(\times 10^{9} / \mathrm{L}\right)$} & $236.5 \pm 59.5$ & $251.2 \pm 36.7$ & ns \\
\hline \multicolumn{2}{|c|}{ Mean platelet volume (fL) } & $11.03 \pm 1.02$ & $10.99 \pm 0.83$ & ns \\
\hline
\end{tabular}

Continuous data are presented as mean $\pm \mathrm{SD}$ or median (interquartile range).

Categorical data are presented as absolute numbers of patients.

Significance of differences were analyzed using Mann-Whitney $\mathrm{U}$ test (continuous data) or Fisher's exact test (categorical data).

The elevation of the three parameters: CRP, NLR and PLR was found in LDIP subgroup in comparison with HDIP subgroup of breast cancer patients (Figure 2). The values for MPVLR were $7.1 \pm 2.7$ for LDIP vs. 6.7 \pm 3.9 for HDIP (NS).

LDIP

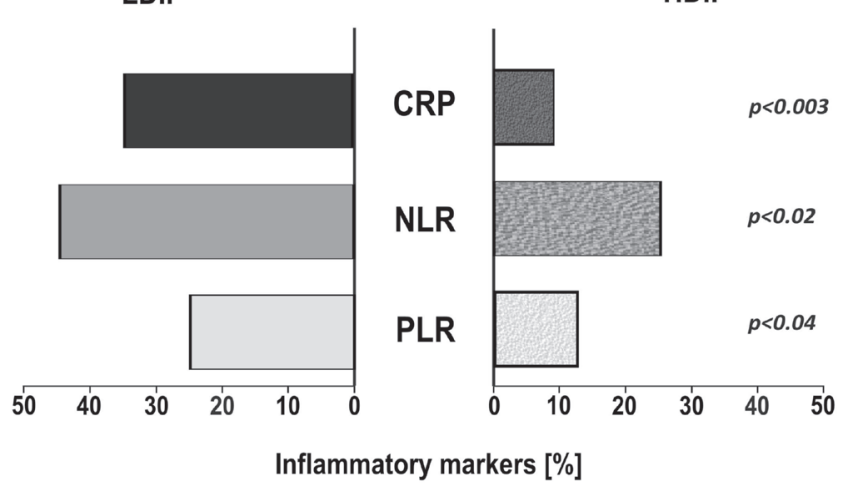

Figure 2. The comparison of plasma inflammatory markers (CRP) and cellular inflammatory markers (NLR, PLR, MPVLR) between breast cancer patients with high dietary polyphenols intake (HDIP) $(\mathrm{n}=39)$ and breast cancers with low dietary polyphenols intake (LDIP) $(\mathrm{n}=39)$.

The results of inflammatory markers are presented as the percentage of individuals above the cut-off point. Cut-off values: CRP $>0.5 \mathrm{mg} / \mathrm{L}$, NLR $>3.0$, PLR $>207.0$. Significance of differences were analysed using Fisher's exact test. CRP: C-Reactive Protein, NLR: neutrophil-to-lymphocyte ratio, PLR: platelet-to-lymphocyte ratio. HDIP - high dietary polyphenols intake, LDIP - low dietary polyphenols intake.
Agreement between selected inflammatory markers and polyphenol dietary intake

A significant association was found between CRP, NLR, PLR but not MPVLR and total polyphenol intake. The highest agreement rate was found for CRP. Agreement between results was assessed using Cohen's kappa test and are presented in Table 3. Concordance between polyphenol intake and inflammatory markers was in the poor to fair range but reached a level of statistical significance.

\section{DISCUSSION}

The aim of this study was to find whether the high polyphenol intake can limit rate of inflammation in breast cancer (BC) patients. We measured CRP and calculated PLR, NLR, MPVLR on the basis of laboratory results of blood morphology and compared the values of these inflammatory markers in two subgroups of breast cancer patients with either lowor high- phenolic dietary intake. All the inflammatory markers studied, with the exception of MPVLR, were found to be remarkably reduced in the group receiving a high dietary intake of polyphenolic compounds. 
Table 2. Cut-off values of inflammatory markers obtained from population of healthy subjects $(\mathrm{n}=102)$

\begin{tabular}{lcccc}
\hline Marker & CRP & NLR & PLR & MPVLR \\
\hline Cut-off value & $>0.5 \mathrm{mg} / \mathrm{L}$ & $>3.0$ & $>207.0$ & $>6.8$ \\
\hline
\end{tabular}

Cut-off values were calculated as 95th percentiles of the inflammatory markers in healthy subjects (control, $\mathrm{n}=102$ ).

CRP: C-Reactive Protein, NLR: neutrophil-to-lymphocyte ratio, PLR: platelet-to-lymphocyte ratio, MPVLR: mean platelet volume-tolymphocyte ratio.

Table 3. Agreement between elevated inflammatory markers and low dietary polyphenol intake in breast cancer patients group $(n=78)$

\begin{tabular}{lcccc}
\hline Marker & $\begin{array}{c}\text { Observed agreement } \\
{[\%]}\end{array}$ & Cohen's kappa & $\begin{array}{c}\text { Confidence interval } \\
(95 \% \text { CI })\end{array}$ & P value \\
\hline CRP & 66.7 & 0,38 & $0.079-0.614$ & $<0.006$ \\
NLR & 60.0 & 0.20 & $-0.010-0.41$ & $<0.04$ \\
PLR & 57.7 & 0.19 & $0.026-0.359$ & $<0.02$ \\
MPVLR & 56.4 & 0.15 & $-0.061-0.354$ & NS \\
\hline
\end{tabular}

The inflammatory markers of breast cancer patients $(\mathrm{n}=78)$.

CRP: C Reactive Protein, NLR: neutrophil-to-lymphocyte ratio, PLR: platelet-to-lymphocyte ratio, MPVLR: mean platelet volume-tolymphocyte ratio.

Our study shows for the first time that high polyphenol intake is associated with lower level of inflammatory markers in $\mathrm{BC}$ patients. The obtained results suggest also that these markers could be useful for estimating the anti-inflammatory effect of a diet. Interestingly, in our earlier work [26] based on the same group of patients, we found a significant difference in platelet aggregation between LDIP vs. HDIP group. In general, platelet aggregation induced in vitro with arachidonic acid, ADP or collagen was higher in LDIP group, which can be explained by pleiotropic activity of polyphenols [26].

NLR and PLR were proposed to be predictive markers in various tumours, including BC [15]. Liu et al. demonstrated that both increased NLR and PLR were associated with poor survival in hormone receptor-negative BC patients. However, NLR was independently correlated with overall survival and disease-free survival, but PLR was not [15]. A metaanalysis found high PLR to be associated with poor overall survival and disease-free survival [32]. In addition, PLR remains a significant prognostic marker for overall survival among patients receiving systemic treatment and patients receiving chemotherapy [31]. These findings suggest that PLR could serve as an indicator of poor prognosis in patients with $\mathrm{BC}$ [32]. The neutrophil lymphocyte ratio (NLR) is a good marker of inflammation, and one which plays an important role in tumour progression and metastasis. However, no association was found between NLR and overall survival in the luminal A and luminal B subtypes of breast cancer patients. Positive results have been obtained elsewhere in the analyses of human epidermal growth factor receptor 2 (HER2)-positive and triple-negative BC subtypes [29]. In another study, NLR and PLR were demonstrated to be independent markers of prognosis in $\mathrm{BC}$ [28].
Although, the comparison of inflammatory markers between breast cancer patients (HDIP and LDIP together) with control (reference group) was not the aim of our study, our results showed that all the inflammatory markers studied are significantly elevated in cancer patients support the usefulness of inflammatory markers in cancer prognosis.

Sun at al. reported that the mean values NLR, and PLR were significantly elevated in BC patients compared to the control group [25]. Moreover, MPV value was significantly higher in $\mathrm{BC}$ group $(\mathrm{p}<0.0001)$ and it was suggested that this parameter can be useful in evaluating $\mathrm{Ki}-67$ proliferation index as well as axillary lymph node metastasis. It was proposed therefore, that MPV could serve as a newly described biomarker for prognosis evaluation amongst BC patients. Losada at al. found an association between low PLR and longer DFS (disease-free survival) in elderly breast cancer patients [17]. Furthermore, they observed longer 3 year overall survival in the low PLR group and longer disease-free survival and overall survival in low NLR subgroup with triple negative breast cancer.

Interestingly, the LDIP group in our study demonstrated a higher NLR value (3.0) than the cut-off point for poor cancer prognosis $(2.5)[4,30]$. A lower polyphenol intake is frequently related to a higher CRP level. Similarly to the observations made in our study, previous reports found the greatest difference between cancer patients cohort and control group in respect to CRP level [30].

A large population-based study found the polyphenol content of the diet to be negatively associated with the INFLA-score of low-grade inflammation biomarkers (CRP, WBC, PLT, GrL) [22]. Although the total INFLA-score was not computed in the present study, the values being its components, including CRP, WBC and PLT, were found to be 
lower in the HDIP group. Interestingly, CRP is the best described inflammatory marker [27] and the preoperative C-reactive protein level is an independent prognostic factor of disease-free survival and overall survival in breast cancer [21]. Our results confirm the key roles reported in the literature for CRP [27], NLR [4] and PLR [28]. The mean platelet volume/ lymphocyte ratio (MPVLR) was described by Hudzik et al. as a good prognostic factor in CVD [8], in our study concerning breast cancer patients, however, it was not useful marker of polyphenol intake.

In this study, in the total group of breast cancer patients (HDIP and LDIP together), the greatest polyphenol sources were tea, dark chocolate, apples, pears, bananas, grapes, berries and whole grain products. This list of sources is similar to that reported for Polish population by Grosso et al., who found the main intake to derive from coffee, tea and chocolate [7] and by Zujko et al., who found it to come from non-alcoholic beverages, fruits, vegetables and cereal products [34]. Chocolate and cocoa products were not found to play such a significant role in the present study as sweets are commonly eliminated from the diet of cancer patients. An increased consumption of fruits and vegetables is commonly observed in cancer patients following diagnosis. Total polyphenol intake in our whole group was $1757 \mathrm{mg} /$ day, which was similar to the findings of Grosso et al. $(1741 \mathrm{mg} /$ day); likewise, flavan-3-ol intake was $608.4 \mathrm{mg}$ /day (our group), $637.3 \mathrm{mg} /$ day [7]. Interestingly, the total consumption of polyphenols in our (Polish) population was found to be comparable to that reported for breast cancer patients in the Western Europe (UK: $1523 \mathrm{mg} /$ day, Germany: $1056 \mathrm{mg} /$ day, Denmark: $1354 \mathrm{mg}$ /day) [13], which strengthen the importance of our findings, making them more universal.

\section{CONCLUSIONS}

Obviously, we are aware that our results, suggesting an association between diet rich in polyphenols and lower inflammatory markers, have been obtained from an small observational cross-sectional study and require further validation in randomized trials on the large cohorts of patients. Nevertheless, in our opinion, these preliminary findings indicate that an antiinflammatory diet is effective in reducing inflammation in the breast cancer patients, which could be an innovative and promising trend in the modern dietetics. A novelty of this study is also showing an usefulness of simple, cheap and commonly available biomarkers for monitoring an anti-inflammatory effects of diet. It is very likely that these markers could be successfully applied to assess a rate of diet-reduced inflammation in other clinical settings where a process of subclinical inflammation poses a significant problem.

\section{Acknowledgments \& funding sources}

This work was supported by the grant "Production of polyphenol extracts of plant origin with antiplatelet and cardioprotective properties - FLAWOPIRYNA" UDA-POIG.01.03.01-10-129/08-00, financed by The European Union from the European Regional Development Fund within the framework of the Innovative Economy Operational Programme.

The study was supported also by the grant from the Medical University of Lodz, Poland (No. 503/6-02001/503-01).

\section{Statement of ethics}

The investigation received the approval of the Bioethical Committee of the Medical University of $\operatorname{Lodz}(R N N / 21 / 16 / K E)$.

\section{Disclosure statement}

The authors report no conflicts of interest.

\section{REFERENCES}

1. Bonaccio M, Pounis $G$, Cerletti C, Donati MB, Iacoviello $L$, de Gaetano $G$. Mediterranean diet, dietary polyphenols and low grade inflammation: results from the MOLI-SANI study. Br J Clin Pharmacol. 2017;83(1):107-113. DOI: 10.1111/bcp.12924.

2. Bray F, Ferlay J, Soerjomataram I, Siegel RL, Torre LA, Jemal A. Global cancer statistics 2018: GLOBOCAN estimates of incidence and mortality worldwide for 36 cancers in 185 countries. CA Cancer J Clin 2018;68(6):394-424. DOI: 10.3322/caac.21492.

3. Cassidy A, Rogers G, Peterson JJ, Dwyer JT, Lin H, Jacques $P F$. Higher dietary anthocyanin and flavonol intakes are associated with anti-inflammatory effects in a population of US adults. The Amer J. Clin Nutr 2015;102(1):172-181. DOI: 10.3945/ajcn.115.108555

4. Ethier JL, Desautels D, Templeton A, Shah PS, Amir $E$. Prognostic role of neutrophil-to-lymphocyte ratio in breast cancer: a systematic review and meta-analysis. Breast Cancer Res 2017;19(1):2. DOI: 10.1186/s13058016-0794-1.

5. Grosso G, Bella F, Godos J, Sciacca S, Del Rio D, Ray $S$, Galvano F, Giovannucci EL. Possible role of diet in cancer: systematic review and multiple meta-analyses of dietary patterns, lifestyle factors, and cancer risk. Nutr Rev 2017;75(6):405-419. DOI: 10.1093/nutrit/ nux012

6. Grosso G, Godos J, Lamuela-Raventos R, Ray S, Micek A, Pajak A, Sciacca S, D'Orazio N, Del Rio D, Galvano $F$. A comprehensive meta-analysis on dietary flavonoid and lignan intake and cancer risk: Level of evidence and limitations. Mol Nutr Food Res 2017;61(4). DOI: $10.1002 / \mathrm{mnfr} .201600930$.

7. Grosso G, Stepaniak U, Topor-Madry R, Szafraniec $K$, Pajak A. Estimated dietary intake and major food sources of polyphenols in the Polish arm of the HAPIEE study. Nutrition 2014;30(11-12):1398-1403. DOI: 10.1016/j.nut.2014.04.012. 
8. Hudzik B, Szkodzinski J, Lekston A, Gierlotka M, Polonski L, Gasior M. Mean platelet volume-to-lymphocyte ratio: a novel marker of poor short- and longterm prognosis in patients with diabetes mellitus and acute myocardial infarction. J Diabetes Complications 2016;30(6):1097-1102. DOI: 10.1016/j.jdiacomp.2016.04.010.

9. Hui C, Qi X, Qianyong Z, Xiaoli P, Jundong Z, Mantian $M$. Flavonoids, flavonoid subclasses and breast cancer risk: a meta-analysis of epidemiologic studies. PLoS One 2013;8(1):e54318. DOI: 10.1371/journal. pone.0054318.

10. Katędkiewicz. E, D $S$-W. Dietary practices and nutritional status in survivors of breast cancer. Rocz Panstw Zakl Hig 2018;69(2):175-182.

11. Koh CH, Bhoo-Pathy N, Ng KL, Jabir RS, Tan GH, See MH, Jamaris S, Taib NA. Utility of pre-treatment neutrophil-lymphocyte ratio and platelet-lymphocyte ratio as prognostic factors in breast cancer. Br J Cancer 2015;113(1):150-158. DOI: 10.1038/bjc.2015.183.

12. Krenn-Pilko S, Langsenlehner U, Thurner EM, Stojakovic T, Pichler M, Gerger A, Kapp KS, Langsenlehner T. The elevated preoperative platelet-to-lymphocyte ratio predicts poor prognosis in breast cancer patients. Br J Cancer 2014;110(10):2524-2530. DOI: 10.1038/bjc.2014.163

13. Kyro C, Zamora-Ros R, Scalbert A, Tjonneland A, Dossus L, Johansen C, Bidstrup PE, Weiderpass E, Christensen J, Ward H, Aune D, Riboli E, His M, ClavelChapelon F, Baglietto L, Katzke V, Kuhn T, Boeing H, Floegel A, Overvad K, Lasheras $C$, Travier N, Sanchez MJ, Amiano P, Chirlaque MD, Ardanaz E, Khaw KT, Wareham N, Perez-Cornago A, Trichopoulou A, Lagiou P, Vasilopoulou E, Masala G, Grioni S, Berrino F, Tumino R, Sacerdote C, Mattiello A, Bueno-de-Mesquita HB, Peeters PH, van Gils C, Borgquist S, Butt $S$, Zeleniuch-Jacquotte A, Sund M, Hjartaker A, Skeie $G$, Olsen A, Romieu I. Pre-diagnostic polyphenol intake and breast cancer survival: the European Prospective Investigation into Cancer and Nutrition (EPIC) cohort. Breast Cancer Res Treat 2015;154(2):389-401. DOI: 10.1007/s10549-015-3595-9.

14. Lei L, Yang Y, He H, Chen E, Du L, Dong J, Yang J. Flavan-3-ols consumption and cancer risk: A meta-analysis of epidemiologic studies. Oncotarget 2016;7(45):7357373592. DOI: 10.18632/oncotarget.12017.

15. Liu C, Huang Z, Wang $Q$, Sun B, Ding L, Meng X, Wu S. Usefulness of neutrophil-to-lymphocyte ratio and platelet-to-lymphocyte ratio in hormone-receptor-negative breast cancer. Onco Targets Ther 2016;94653-4660. DOI: $10.2147 /$ OTT.S106017.

16. Losada-Echeberria M, Herranz-Lopez M, Micol V, Barrajon-Catalan E. Polyphenols as Promising Drugs against Main Breast Cancer Signatures. Antioxidants (Basel) 2017;6(4). DOI: 10.3390/antiox6040088.

17. Losada B, Guerra JA, Malon D, Jara C, Rodriguez $L$, Del Barco S. Pretreatment neutrophil/lymphocyte, platelet/lymphocyte, lymphocyte/monocyte, and neutrophil/monocyte ratios and outcome in elderly breast cancer patients. Clin Transl Oncol 2018. DOI: 10.1007/ s12094-018-1999-9.
18. Luzak B, Golanski J, Przygodzki T, Boncler M, Sosnowska D, Oszmianski J, Watala C, Rozalski M. Extract from spent hop (Humulus lupulus L.) reduces blood platelet aggregation and improves anticoagulant activity of human endothelial cells in vitro. J Funct Foods 2016;22257-269. DOI: 10.1016/j.jff.2016.01.029.

19. Mileo AM, Miccadei S. Polyphenols as Modulator of Oxidative Stress in Cancer Disease: New Therapeutic Strategies. Oxid Med Cell Longev 2016;20166475624. DOI: $10.1155 / 2016 / 6475624$.

20. Nelson SH, Brasky TM, Patterson RE, Laughlin GA, Kritz-Silverstein D, Edwards BJ, Lane D, Rohan TE, Ho GYF, Manson JE, LaCroix AZ. The Association of the C-Reactive Protein Inflammatory Biomarker with Breast Cancer Incidence and Mortality in the Women's Health Initiative. Cancer epidemiology, biomarkers \& prevention: a publication of the American Association for Cancer Research, cosponsored by the American Society of Preventive Oncology 2017;26(7):1100-1106. DOI: 10.1158/1055-9965.epi-16-1005.

21. Pierce BL, Ballard-Barbash R, Bernstein L, Baumgartner RN, Neuhouser ML, Wener MH, Baumgartner $K B$, Gilliland FD, Sorensen BE, McTiernan A, Ulrich $C M$. Elevated biomarkers of inflammation are associated with reduced survival among breast cancer patients. J. Clin. Oncol.: official journal of the American Society of Clinical Oncology 2009;27(21):3437-3444. DOI: 10.1200/jco.2008.18.9068.

22. Pounis G, Bonaccio M, Di Castelnuovo A, Costanzo S, de Curtis A, Persichillo M, Sieri S, Donati MB, Cerletti $C$, de Gaetano $G$, Iacoviello L. Polyphenol intake is associated with low-grade inflammation, using a novel data analysis from the Moli-sani study. Thromb Haemost 2016;115(2):344-352. DOI: 10.1160/th15-06-0487.

23. Ramirez AG, Parma DL, Munoz E, Mendoza KD, Harb $C$, Holden AEC, Wargovich M. An anti-inflammatory dietary intervention to reduce breast cancer recurrence risk: Study design and baseline data. Contemp Clin Trials 2017;571-7. DOI: 10.1016/j.cct.2017.03.009.

24. Sak $K$. Intake of Individual Flavonoids and Risk of Carcinogenesis: Overview of Epidemiological Evidence. Nutr Cancer 2017;69(8):1119-1150. DOI: 10.1080/01635581.2017.1367934.

25. Sun H, Yin C-q, Liu Q, Wang F, Yuan C-h. Clinical Significance of Routine Blood Test-Associated Inflammatory Index in Breast Cancer Patients. Medical Science Monitor 2017;235090-5095. DOI: 10.12659/ msm.906709.

26. Sut. A.; Pytel MZ, M.; Różalski, M.; Golański, J.: Dieta bogata $\mathrm{w}$ polifenole roślinne obniża agregację płytek krwi u kobiet $\mathrm{z}$ rakiem piersi. [A polyphenol-rich diet is associated with decreased platelet aggregation in breast cancer patients]. Diagn Lab 2018;54(2):1 - 4.

27. Wang J, Lee IM, Tworoger SS, Buring JE, Ridker PM, Rosner B, Hankinson SE. Plasma C-reactive protein and risk of breast cancer in two prospective studies and a meta-analysis. Cancer epidemiology, biomarkers \& prevention : a publication of the American Association for Cancer Research, cosponsored by the American Society of Preventive Oncology 2015;24(8):1199-1206. DOI: 10.1158/1055-9965.epi-15-0187. 
28. Wariss BR, de Souza Abrahao K, de Aguiar SS, Bergmann A, Thuler LCS. Effectiveness of four inflammatory markers in predicting prognosis in 2374 women with breast cancer. Maturitas 2017;10151-56. DOI: 10.1016/j.maturitas.2017.04.015.

29. Wei B, Yao M, Xing C, Wang W, Yao J, Hong Y, Liu Y, Fu $P$. The neutrophil lymphocyte ratio is associated with breast cancer prognosis: an updated systematic review and meta-analysis. Onco Targets Ther 2016;955675575. DOI: 10.2147/OTT.S108419.

30. Wojcik E, Stasik Z, Rychlik U, Tarapacz J, Kulpa J, Brandys K.: Wskaźniki NLR i PLR w ocenie rokowania chorych na niedrobnokomórkowego raka płuca. [NLR and PLR ratios in prognostic assessment of non-small cell lung cancer patients]. Diagn Lab 2016;52(1):13-20.

31. Xu J, Ni C, Ma C, Zhang L, Jing X, Li C, Liu Y, Qu X. Association of neutrophil/lymphocyte ratio and platelet/lymphocyte ratio with ER and PR in breast cancer patients and their changes after neoadjuvant chemotherapy. Clin Transl Oncol 2017;19(8):989-996. DOI: 10.1007/s12094-017-1630-5.

32. Zhu Y, Si W, Sun Q, Qin B, Zhao W, Yang J. Platelet-lymphocyte ratio acts as an indicator of poor prognosis in patients with breast cancer. Oncotarget 2017;8(1):10231030. DOI: 10.18632/oncotarget.13714.

33. Zujewski JA. Changing Paradigms in Breast Cancer Therapeutics: An Extended Abstract. Med Princ Pract 2016;25 Suppl 273-75. DOI: 10.1159/000443502.

34. Zujko ME, Witkowska AM, Waskiewicz A, Sygnowska E. Estimation of dietary intake and patterns of polyphenol consumption in Polish adult population. Advances in medical sciences 2012;57(2):375-384. DOI: 10.2478 / v10039-012-0026-6.

Received: 16.01 .2019

Accepted: 25.03.2019 